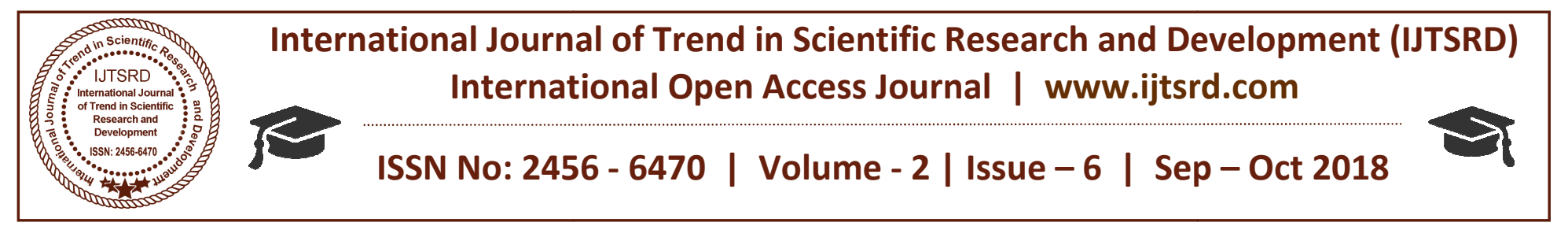

\title{
Effect of Diesel Engine Fuelled with Biofuel Blends
}

\author{
Akash Paul $^{1}$, Amiya Bhaumik², Kushal Burman ${ }^{2}$ \\ ${ }^{1}$ Lecturer, ${ }^{2}$ Assistant Professor \\ Mechanical Engineering Department, Technoindia - Saltlake, \\ Kolkata, West Bengal, India
}

\section{ABSTRACT}

The present work was conducted on a 1-cylinder, $4 \mathrm{~S}$, DI CI engine, on which neat diesel, neem biodiesel and polanga biodiesel and ethanol fuel were tested by varying the load on the engine setup at various blend ratios such as: - diesel fuel 100\% (D100), biodiesel neem $100 \%$ (N100), biodiesel polanga $50 \%$ blended with diesel 50\% (P50), and ethanol $5 \%$ blended with diesel $95 \%$ (E5). The research carried was to compare the performance-emission characteristics of various blend samples w.r.t neat diesel fuel. The performance results show that, the BTE of N100, P50 fuel blends was less than E5 blend, as compared to neat diesel, whereas, the BSFC of D100, E5 blend had a decreasing nature than $\mathrm{N} 100$ and P50 blend. The CO emissions among the biofuel blends was maximum for N100 and then P50 blend but the least was for E5 blend w.r.t neat diesel. Also, the UHC emission for N100, P50 and E5 blends had a decreasing trend than neat diesel fuel. The D100 fuel had a maximum NOx emission in comparison to others and the least was by E5 blend. The CO2 emission of N100 and D100 was the highest than P50 and E5 blends during the operation. The unused O2for N100 fuel was the least than other fuel samples and the maximum was for E5 blend. The biofuel blends being used here had an effective outcome which can be utilised as an substitute for neat diesel.

Keyword: Performance, emission, diesel engine, neem biodiesel, polanga biodiesel, ethanol.

\section{INTRODUCTION}

The major issue being faced every day is the shortage of the petroleum oil in their origin, due to the excessive utilisation in automobiles, industries, etc. along with the increasing cost at various nations. With the excessive population, the need is inevitable. So, majorly petroleum oil is used in diesel engine, since it gives high efficiency along with heavy exhaust emission gases (i.e., PM, soot, smoke, $\mathrm{CO}_{2}, \mathrm{NO}_{\mathrm{x}}$, UHC, CO). Though in the modern world with the emission regulation, new cutting edge innovative technology (mechanisms such as: CRDI, IDI, EGR, EGAT, etc.) to develop CI engine for reducing emissions from the engines. This emission has an adverse effect on the environment leading to climatic change, global warming, increased greenhouse gases; which directly or indirectly effects ourselves as well as the other living creatures, making them extinct in some areas. So, in order to cope up with the present scenario we need divert our attention towards alternative fuel technology, to fulfil the scarcity of petroleum products, save the environment, living creatures, reduce our dependence of oil import. Biodiesel is an effective alternate to petroleum oil, since, it is biodegradable, non-toxic, renewable, environmental friendly, easily grown and produced in the locality, reduce cost of oil if used in mass quantity. Also, biodiesel reduces greenhouse gas emissions, promote rural development by growing biodiesel plants such as neem, polanga, ricebran, thumba, jatropha, karanja, cottonseed, etc. which will increase farm economy, develop a global agricultural market as well. The biodiesel fuel can be directly injected in the engine and there is no need for any external or internal setup. Also, alcohols such as: methanol, ethanol, propanol, butanol, etc. were operated earlier in CI engines by blending with diesel and were being used in some nations as well. [1-2].

In the alternative fuel region, number of research has been done and which are being followed as. One researcher studied the effect of methyl ester at $15 \%$ blended with diesel-ethanol and diesel-butanol blends on combustion and emission of diesel engine, and results show that $15 \%$ of methyl esters was enough to 
avoid phase separation of diesel-alcohol blends, and also the use of diesel-alcohol blends reduced $\mathrm{CO}$ and soot emissions w.r.t biodiesel blends with the same oxygen content [3]. Another investigation was done on a 4-cylinder, 4S, DI diesel engine using anhydrous bio-ethanol-diesel blended with $10 \%$ ethanol in volume, the results which were obtained reveal a significant decrease on particulate emissions with no increment in other gaseous emissions [4]. With different blends of polanga biodiesel being operated on a single cylinder, diesel engine and when compared with diesel fuel, the polanga biodiesel blends resulted into improved performance and reduced emission w.r.t diesel fuel [5].Addition of ethanol as an oxygen at eadditive and dodecanol as the solvent to diesel shows higher brake specific fuel consumption with slight increase in brakethermalefficiency,howeverhigherethanolcontentr educescetanenumberofdiesel [6].Mohammadi et al. reported that blending ethanol with diesel fuel is effective in reducing nitrogen oxides (NOx) and particulate matter (PM),alsothe blending of fuel increased the $\mathrm{HC}$ and $\mathrm{CO}$ emissions [7]. Akash Paul et al. found the BTE of ethanol 10\% blend with diesel fuel was highest along with least BSFC for ethanol $10 \%$ blend, whereas, the $\mathrm{CO}, \mathrm{UHC}, \mathrm{NO}_{\mathrm{x}}$ got decreased for Thumba $100 \%$ and polanga biodiesel $30 \%$ when blended with diesel fuel [8].Another researcher, utilised biodiesel Jatropha- diesel blends along with a multi-DM-32dieseladditive, and the results show comparable performance efficiencies, and produce lowersmoke, $\mathrm{CO}_{2}$ and $\mathrm{CO}$ emissions [9].

\section{METHODOLOGY}

The fuels chosen for this present work were conventional diesel fuel, biodiesel neem, biodiesel polanga and ethanol. The fuels have been brought from the local market. The properties of the oil samples have been displayed in Table 1 . The engine setup being employed for this operation consists of a 1-cylinder, 4S, water-cooled, DI, CI diesel engine, engine test bed, and also exhaust gas analyser for measuring the emission outputs from diesel engine exhaust gas. The investigation engine setup is shown in Fig. 1, and Table 2displays the engine details.

Table 1: Properties of Oil samples

\begin{tabular}{|c|c|c|c|c|}
\hline Properties & Diesel & Neem Bio-diesel & Polanga Bio-diesel & Ethanol \\
\hline Density, $\mathrm{kg} / \mathrm{m}^{3}$ at $20^{\circ} \mathrm{C}$ & 842.4 & 912 & 889 & 788 \\
\hline Calorific Value, $\mathrm{KJ} / \mathrm{kg}$ & 42510 & 39500 & 38550 & 26800 \\
\hline Cetane Number & 50 & 51 & 57.3 & 8 \\
\hline Kinematic viscosity, $\mathrm{x} 10^{-2} \mathrm{~m}^{2} / \mathrm{s}$ at $20^{\circ} \mathrm{C}$ & 2.8 & 7.5 & 5.2 & 1.2 \\
\hline Latent heat of evaporation, $(\mathrm{kJ} / \mathrm{kg})$ & 252 & 265 & 200 & 840 \\
\hline Flash point $\left({ }^{\circ} \mathrm{C}\right)$ & 79 & 65 & 151 & 13.5 \\
\hline Auto-ignition temperature, $\left({ }^{(\mathrm{C})}\right.$ & 251 & 288 & 363 & 420 \\
\hline Oxygen content $(\mathrm{wt} \%)$ & 0 & 13 & 10 & 34.8 \\
\hline
\end{tabular}

For blending of neem biodiesel with diesel fuel, and blending of ethanol with diesel fuel did not require any engine modification, the fuel samples were directly inhaled by the engine.

For this investigation, the fuel blend samples prepared were - diesel fuel 100\% (D100), biodiesel neem 100\% (N100), biodiesel polanga 50\% blended with diesel 50\% (P50), and ethanol 5\% blended with diesel 95\% (E5). The engine was initially inhaled with neat diesel fuel and was operated by varying the load conditions as: $0 \%, 25 \%, 50 \%, 75 \%$ and $100 \%$, to get the base data for diesel and to make an analysis in between the performance and emission data of different fuel blends. Any new blend before beginning the experiment, the engine was operated for sufficient time till the last drop to wipe out the leftover fuel droplets from the previous tests.

Table 2: Engine details

\begin{tabular}{|c|c|}
\hline Parameters & Outputs \\
\hline Make-Model & Kirloskar-Varsha \\
\hline No. of Cylinder & Single \\
\hline Bore X stroke & $75 \mathrm{~mm} \mathrm{X} 80 \mathrm{~mm}$ \\
\hline Max. power & $3.12 \mathrm{~kW}$ \\
\hline Compression Ratio & $20: 1$ \\
\hline Engine speed & $1500 \mathrm{rpm}$ \\
\hline CC Position & Vertical \\
\hline Ignition method & Compression Ignition \\
\hline
\end{tabular}




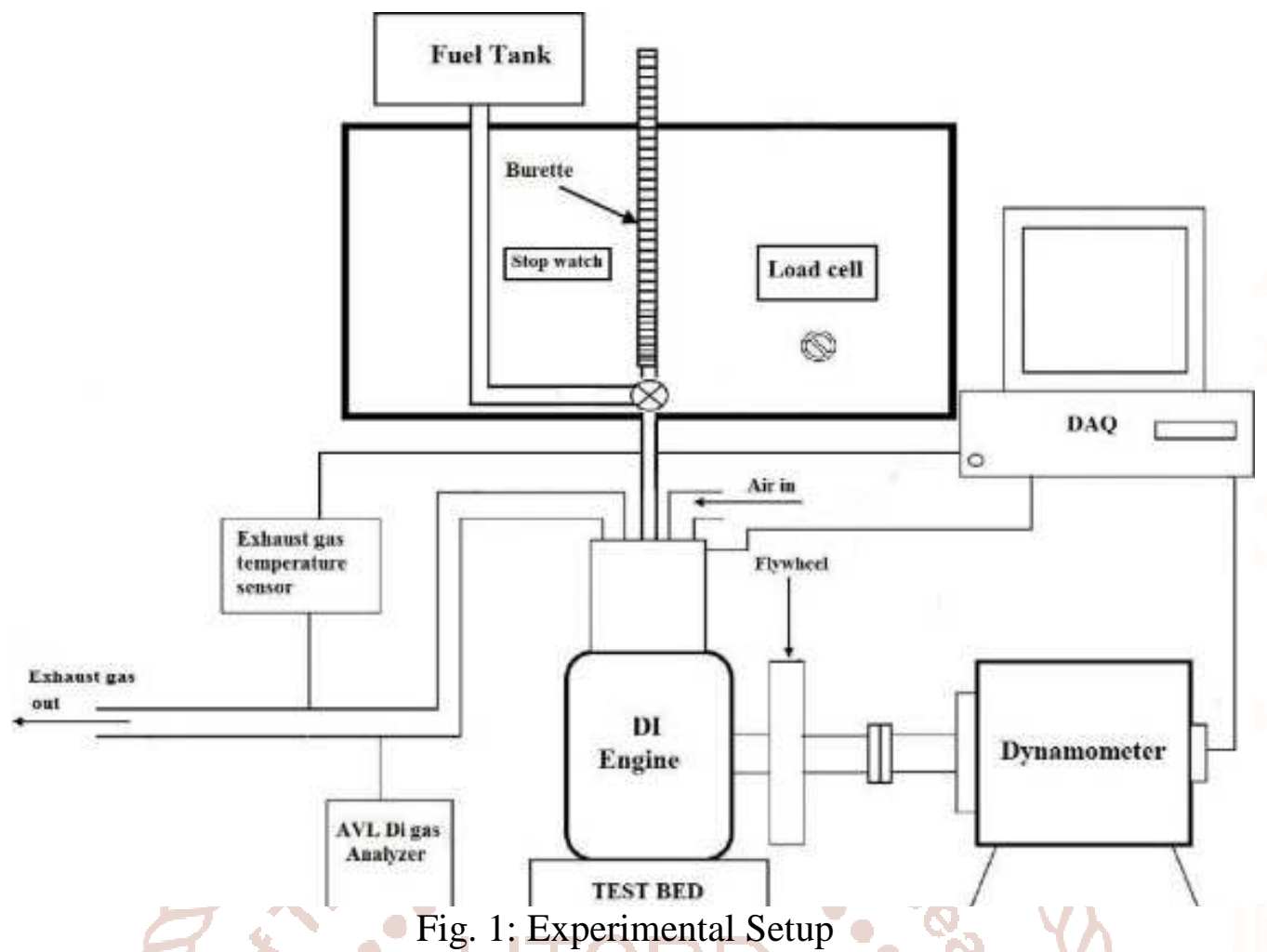

To maintain the constant speed (i.e., 1500rpm) of the engine, special attention was taken and the data authenticity was increased by taking 5successive readings for each fuel blends and at last averaged them to get the final data for the diesel engine. The entire investigation was conducted on an isolated space at a temperature of $27^{\circ} \mathrm{C}$. The performance values such as BTE and BSFC were displayed on the DAQ system, whereas, for the exhaust emissions values such as $\mathrm{CO}, \mathrm{UHC}$ and $\mathrm{NO}_{\mathrm{X}}$ were measured by AVL 5 gas analyzer.

\section{RESULT \& DISCUSSIONS}

The current research showcases the detailed discussions of performance and emission parameters for the different fuel blends which are as follows:

\section{A. Brake Thermal Efficiency}

Fig. 2 demonstrates the variation of Brake thermal efficiency w.r.t Load for various fuel blends. In all the fuel blends it was found thatE5 blend shown increased BTE at full load, which might be because of increased auto-ignition temperature, low viscosity and reduced density of ethanol. The BTE for D100 increased with the rise in the percentage of load as well but at the full load it decreased. For N100 i.e., neem biodiesel, the BTE was decreased

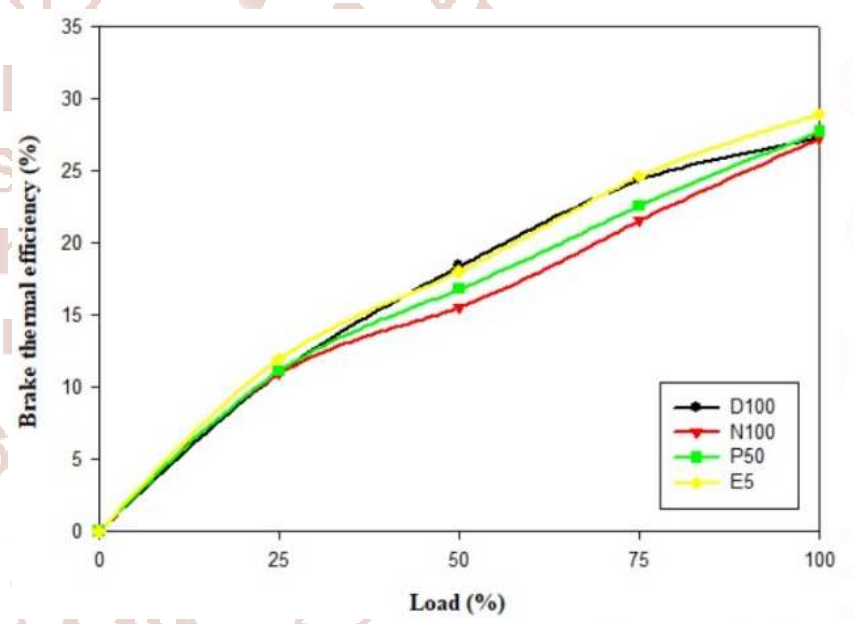

Fig. 2: Brake thermal efficiency w.r.t Load

Throughout the operation in comparison to D100, which might be because of richness of neem biodiesel kinematic viscosity; due to which, the fuel could not get much leaner in order to produce increased BTE. Also, the BTE for P50 blend was lower throughout the operation.

\section{B. Brake Specific Fuel Consumption}

Fig. 3 demonstrates the change of Brake Specific Fuel Consumption w.r.t Load for all fuel blends. The BSFC displays a decreasing nature during the whole operation for all the blend samples. For E5 blend, the BSFC was the least throughout. The BSFC of N100 was highest w.r.t other fuel blends, but decreased with the increase in load equivalent. This may be due to the 


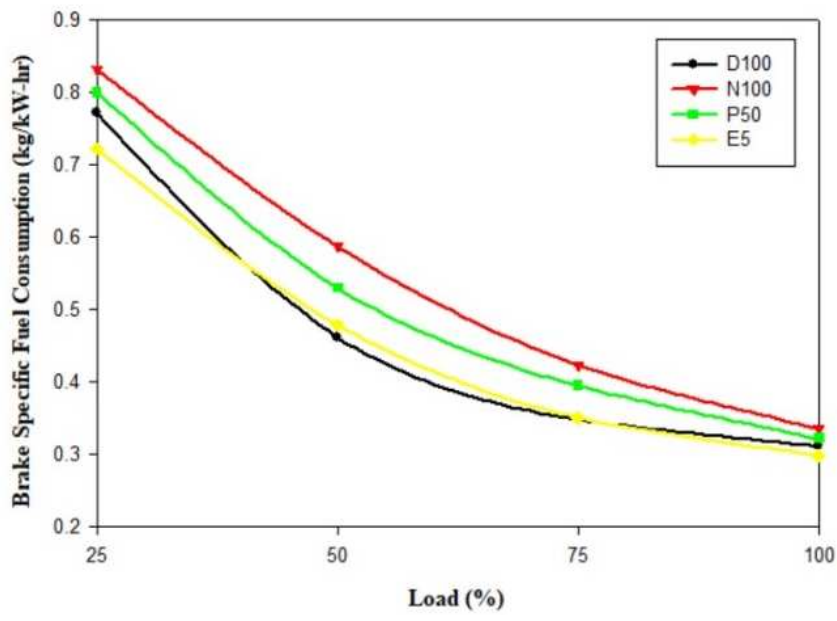

Fig. 3: Brake specific fuel consumption w.r.t Load

\section{Unburnt Hydrocarbon}

Fig. 5 demonstrates the Unburnt Hydrocarbon w.r.t Load for all fuel blends. The UHC emission for all the blends increase in the initial phase but later decrease throughout, which might be due to better combustibility after the zero load condition. The UHC of diesel fuel was higher throughout the operation. The N100 fuel shown decreased UHC emission w.r.t neat diesel, which may be due to increased $\mathrm{CN}$ of biodiesel neem. The P50 blend shown lesser UHC emission w.r.t neat diesel and T100, but the least was shown by E10 blend as compared to other fuel samples; the increase in oxygen content of ethanol in blend may be the cause.

increased viscosity of neem biodiesel that in order to produce the same power output the consumption of fuel was maximum than other fuels. The BSFC of P50 blend also decreased throughout the operation but it's BSFC was more than neat diesel and E5 blend. The same reason as prescribed for N100 fuel is also stated here as well, since the percentage of polanga biodiesel was $50 \%$ in volume and the rest is neat diesel, so the BSFC for P50 blend is lesser than N100.

\section{Carbon Monoxide}

Fig. 4 demonstrates the variation of Carbon Monoxide w.r.t Load for all fuel blends. The CO for neat diesel i.e., D100 fuel was increased throughout the entire duration. Whereas, the CO emission for N100, P50 and E5 blends shows a decreasing nature w.r.t D100, which may be due to the richness of oxygen content of biodiesel neem and ethanol percentage in fuel blends along with addition of diesel fuel. The blends P50 showed decrease CO emission next toE5 blend, whereas, the N100 fuel also shown less CO than neat diesel but more than the other blends.

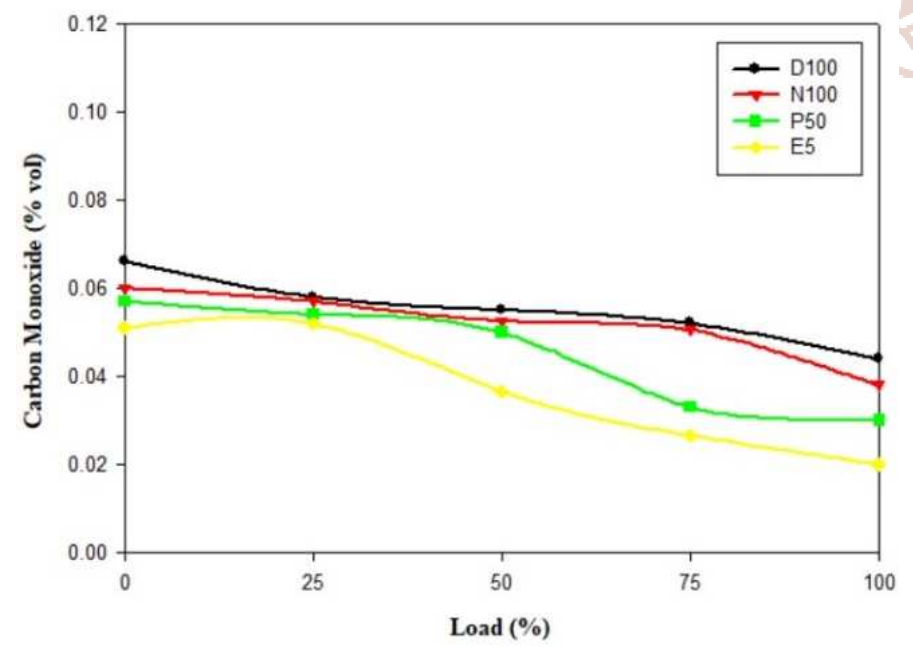

Fig. 4: Carbon monoxide w.r.t Load

\section{E. Oxides of Nitrogen}

Fig. 6 demonstrates the change of Oxides of Nitrogen w.r.t Load in all fuel blends. The $\mathrm{NO}_{\mathrm{x}}$ emission showed an increased trend during the whole procedure, which may be due to increase in incylinder temperature with the load increment. The $\mathrm{NO}_{\mathrm{x}}$ emission for D100 was increased entirely. The $\mathrm{N} 100$ fuel $\mathrm{NO}_{\mathrm{x}}$ emission got decreased than diesel fuel in comparison to other blends. The $\mathrm{NO}_{\mathrm{x}}$ emission for P50 blend further decreased from neat diesel and neem biodiesel, but the $\mathrm{NO}_{\mathrm{x}}$ emission was least for E10 blend.

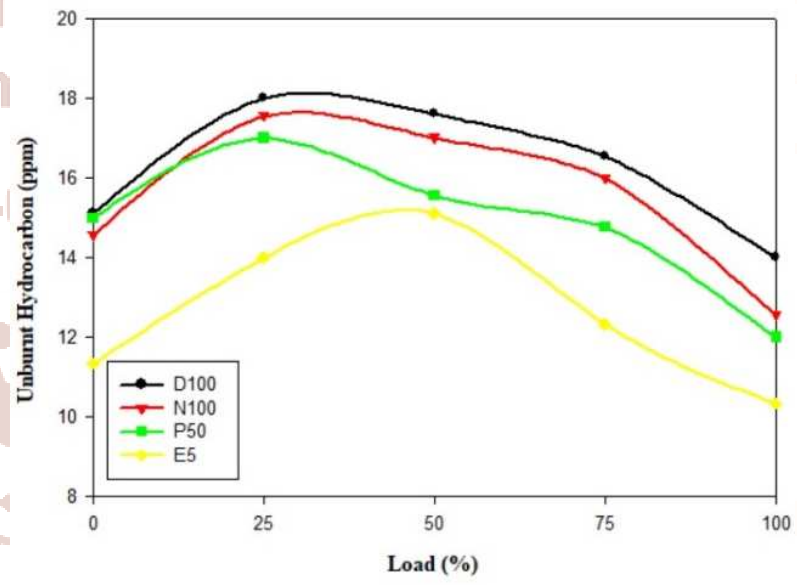

Fig. 5: Unburnt hydrocarbon w.r.t Load

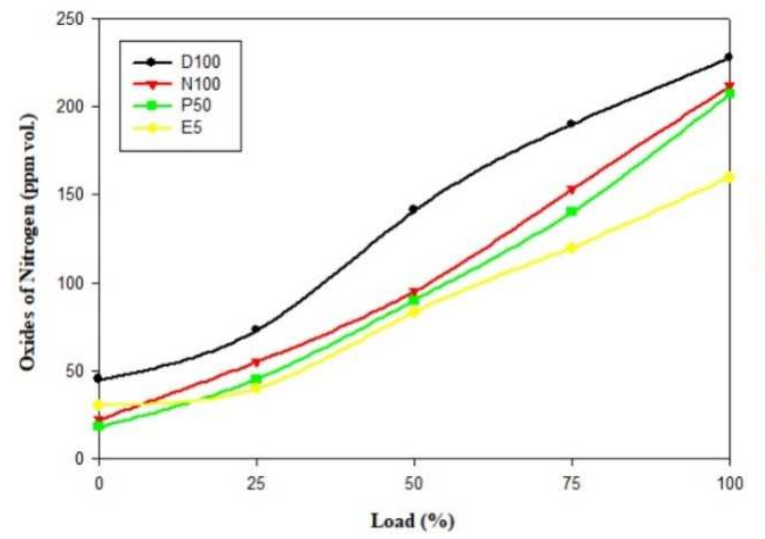

Fig. 6: $\mathrm{NO}_{\mathrm{x}}$ w.r.t Load 


\section{F. Carbon Dioxide}

Fig. 7 demonstrates the change of Carbon Dioxide w.r.t Load for all fuel blends. The $\mathrm{CO}_{2}$ emissions increased at all load conditions in all fuel samples. The N100 and D100 fuels had an increased $\mathrm{CO}_{2}$ than P50 blend. The $\mathrm{CO}_{2}$ emission was lower for E5 blend w.r.t other fuel samples.

\section{G. Unused Oxygen}

Fig. 8 demonstrates the variation of Unused Oxygen w.r.t Load for all fuel blends. The unused $\mathrm{O}_{2}$ for N100 fuel was the least as compared to other fuel samples. The unused $\mathrm{O}_{2}$ of E5 blend was maximum throughout when comparing to fuel samples. P50 blend unused $\mathrm{O}_{2}$ was lower than neat diesel but more than E5 blend.

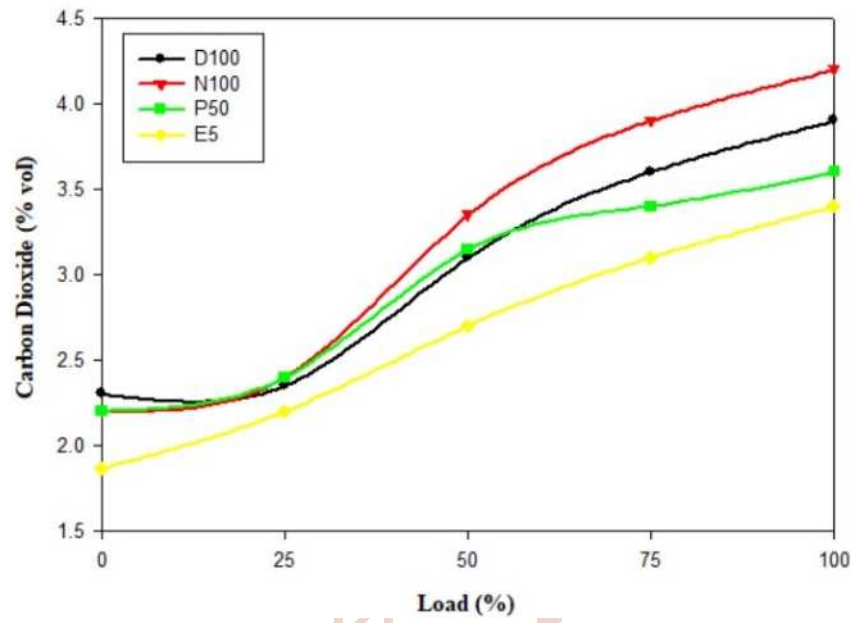

Fig. 7: Carbon Dioxide w.r.t Load

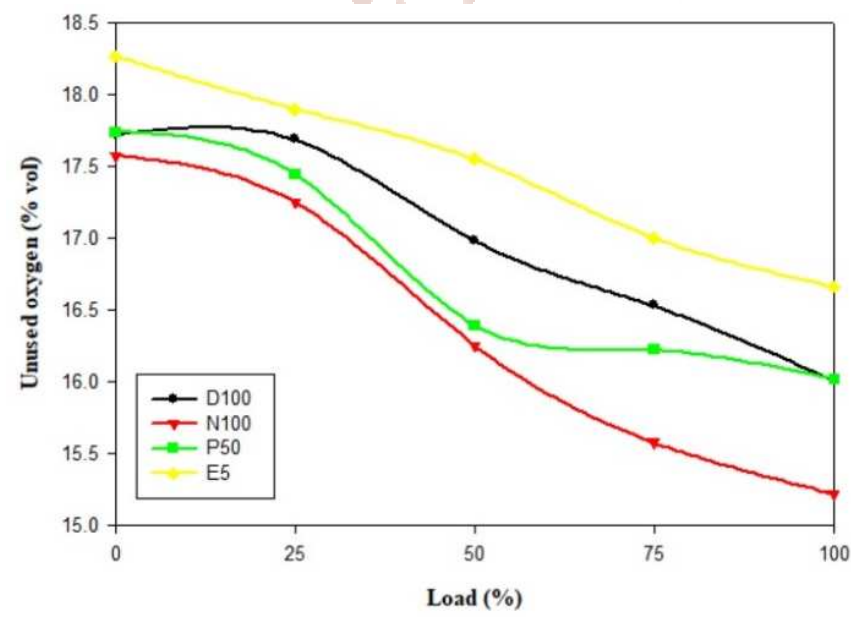

Fig. 8: Unused Oxygen w.r.t Load

\section{CONCLUSIONS}

In this current research work, the entire operation was carried on a 1-cylinder, 4S, DI CI engine. The performance results show that, the BTE of N100, P50 fuel blends was less than E5 blend, although for neat diesel, the BTE was increase from the beginning but at full load it got decreased than the rest; whereas, the
BSFC of D100, E5 blend had a decreasing nature than N100 and P50 blend. At full load, the least BSFC for E5 blend in comparison to other fuel samples. The CO emissions among the biofuel blends was maximum for N100 and then P50 blend but the least was for E5 blend w.r.t neat diesel. Also, the UHC emission for N100, P50 and E5 blends had a decreasing trend than neat diesel fuel. The $\mathrm{D} 100$ fuel had a maximum $\mathrm{NO}_{\mathrm{x}}$ emission in comparison to others and the least was by E5 blend. The $\mathrm{CO}_{2}$ emission of $\mathrm{N} 100$ and D100 was the highest than P50 and E5 blends during the operation. The unused $\mathrm{O}_{2}$ for $\mathrm{N} 100$ fuel was the least than other fuel samples and the maximum was for E5 blend. The performance and emission outputs forE5 blend is better; but the other blends output results were close enough to that of E5 blend, so those blends can also be utilized in CI engines. The blends carried for $/ /$ analysing the performance-emission characteristics with diesel fuel had an effect on the outputs, and similar kind of results were obtained by other researchers as well. So, with the necessity of alternative fuel in diesel engines, the petroleum fuel product import will decrease and the production of these alternative biofuel will rise, reducing their initial manufacturing cost and creating our clean environment to breathe.

\section{REFERENCES}

1. Akash Paul, Amiya Bhaumik, Kushal Burman. Effect of performance and emission parameters fuelled with Biofuel blends on diesel engine. International Journal of Innovative Science and Research (IJISRT), Volume 3 Issue 9, Sep - 2018, $399-402$.

2. Akash Paul, Amiya Bhaumik, Kushal Burman. Study of engine performance and emission trend fuelled with Biodiesel-Diesel blends. International Journal of Innovative Science and Research (IJISRT), Volume 3 Issue 9, Sep - 2018, 395 398.

3. Sukjit E, Herreros J M, Dearn K D, GarcíaContreras R, Tsolakis A. The effect of the addition of individual methyl esters on the combustion and emissions of ethanol and butanol -diesel blends. Energy June 2012;42(1):364-374.

4. Lapuerta M, Armas O, Herreros J M. Emissions from a diesel-bioethanol blend in an automotive diesel engine. Fuel January 2008; 87(1):25-31. ISSN 0016-2361. 
5. Akash Paul, Amiya Bhaumik, Kushal Burman. Effect of Diesel-Biodiesel fuel blends on diesel engine performance and emission characteristics. International Journal of Emerging Technology and Advanced Engineering (IJETAE), Volume 8 Issue 9, Sep - 2018, $69-73$.

6. Yao C. D., Zhang Z. H., Xu Y. L.and Huang Y., 2008. Experimental investigation of effects of bioadditives on fuel economy of the gasoline engine. Science in China Series E: Technological Sciences.
7. Mohammadi A, Kee S, Ishiyama $T$, Kakuta $T$, Matsumoto T. Implementation of ethanol diesel blend fuels in PCCI combustion, SAE tech paper 2005; SAE 2005- 01-3712.

8. Akash Paul, Amiya Bhaumik, Kushal Burman. Effect of biodiesel blends on diesel engine. International Journal of Trend in Scientific Research and Development (IJTSRD), Volume 2 Issue 6, Oct - 2018, 1317 - 1320.

9. Proceedings of I Mech E Part D: Journal of Automobile Engineering 219 (D):13904.

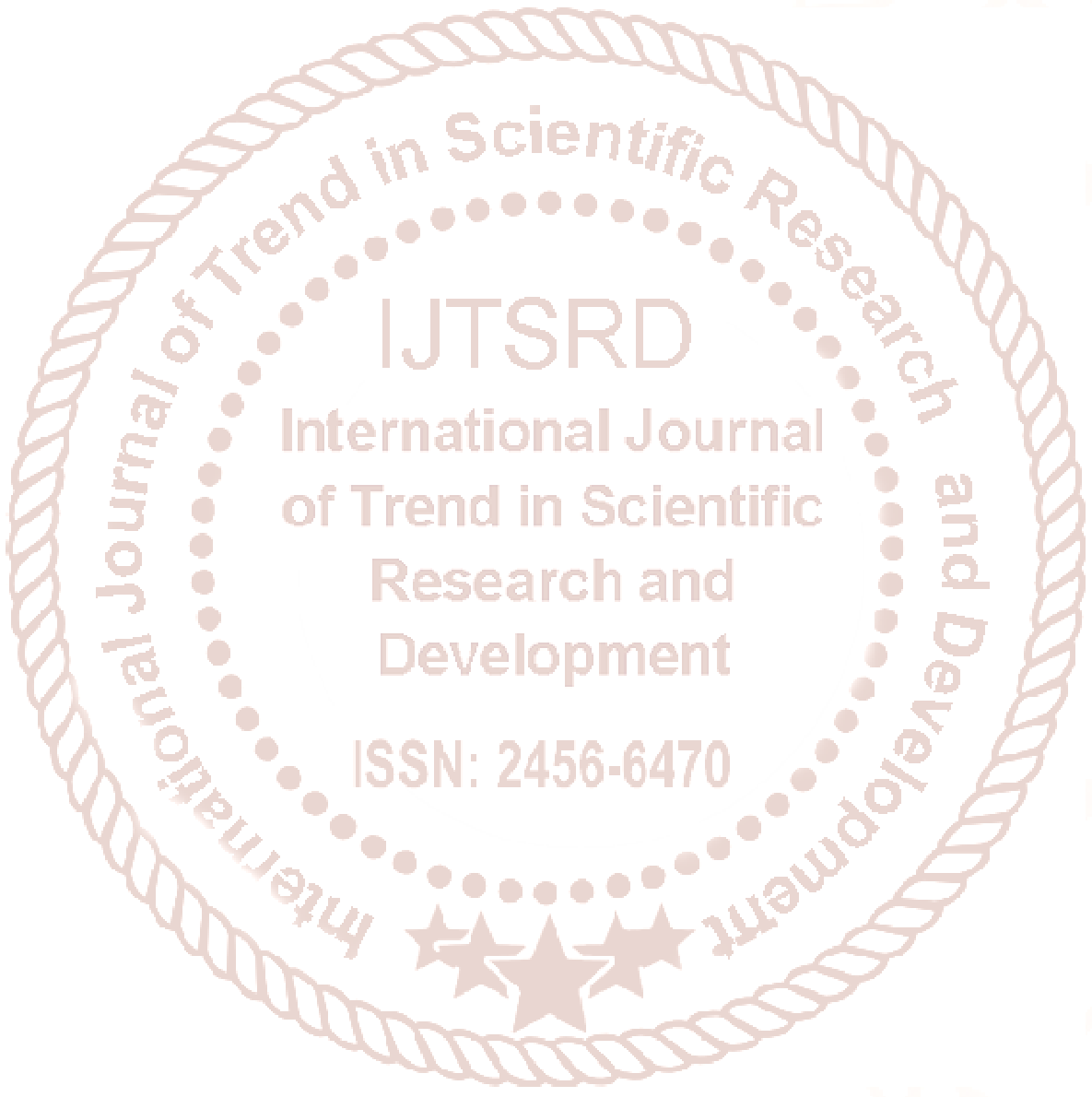

